\title{
Contemporary Investigations of Pakistan Food Insecurity and Trends of Global Food Supply and Demand
}

\author{
Zia-Ullah Muhammad ${ }^{1}$, Shumaila Naz Akhter ${ }^{2}$, Muhammad Imran Hanif $^{3}$, \\ Muhammad Kafayat Ullah ${ }^{4}$ \\ ${ }^{1,3}$ Ph. D Scholar-School of Management and Economics, University of Electronic Science and Technology of \\ China \\ ${ }^{2}$ Virtual University of Pakistan \\ ${ }^{3,4}$ Al-Haseeb Public High School, Block No. 39 Dera Ghazi Khan, Pakistan
}

\begin{abstract}
This paper is an overview to a collection of reviews about situation of global food supply and demand. It has discussed the major drivers affecting the demand and consumption patterns of food in the world. Despite that state of food insecurity of Pakistan has been reported and highlights the few causes of this phenomenon. Indeed, there are 852 million people are hungry in the world and that are living in the developing countries. It is required to design food policy that should serve humanity to improve the accomplishment of humanitarian goals of eradicating extreme poverty and hunger. However, these goals have become quite challenging by emerging rapid increase in population growth, climate change, energy crises, credit crises, water scarcity and instability of peace. It is essentials to increase the production of high quality of food with reduced inputs to feed billions of people in the world. Hence new technologies must be developed to accelerate the crops production and focus on those traits which possessed the greatest potential to enhance the yield.
\end{abstract}

Keywords: food security, crops production, food crops, food supply and demand.

\section{Introduction}

Food security as a concept has been originated during the global food crises in the mid-1970s. Initially the focus of attention was referred as food supply, availability assurance and to some extent price stability of basic foods stuff at the national and international level [1]. Food security refers to "when all people, at all times, have physical, social and economic access to sufficient, safe and nutritious food to meet their dietary needs and food preferences for an active and healthy life" [2]. However, food insecurity is defined as "Limited or uncertain availability of nutritionally adequate and safe foods or limited or uncertain ability to acquire acceptable foods in socially acceptable ways."'[3]. According to WHO there are three pillars to determine the food security as food availability, food access, and food use [4], While FAO described four pillars for measuring food security status likewise availability, access, utilization, and stability [2]. In the past there are many definitions of food security reviewed in the literature [4]. According to Millennium Development Goals (MDGs) 2015 reduction in food insecurity, hunger, child mortality rates, and to ensure environmental sustainability are integral and prerequisite for economic development. Economic development and food security are mutually reinforcing process in the course of development [5]. Nonfood sovereign state refers to the extent to which a country unable to produce the needed food and has not resources to buy food from the international market to accomplish demand and supply gap. [6]. Therefore it is fundamental and backbone for national security which is generally ignored [7].

Mainly the objective of this study is to look and evaluates the contemporary state of Pakistan food insecurity and highlights the drivers impacting on food supply and consumption patterns with comprehensive over view of global food supply and demand. Food availability is the function of home production and imports [8]. It refers as supply of (quantities \& quality of nutritious) food through production, distribution and exchange [9]. Food production consists on factors such as land use and tenure, crop breeding, selection of soil crop, livestock breeding management and harvesting. Whereas food distribution involves a series of post-harvest activities including the processing, storage, packaging, transportation and marketing of food, besides these activities related to household purchasing power, food exchanges, gift giving , traditions of food use (including child feeding practices) and public food distribution[10]. The third component of food availability is exchange of food which is related with the efficient trading systems and market institutions [11]. Despite that storage techniques and food chain infrastructure significantly impact on food wastage and distribution [12]. Similarly rainfall and temperature effects on crops production [9]. Substantially food supplies have grown faster as compared to the population in the developing countries, in this way food availability per person has improved and dietary energy supplies have also risen faster than required average dietary energy. Thus level of energy adequacy has higher in the developing regions. In fact energy supplies has risen $10 \%$ relative to the average dietary energy requirements in the developing regions during the last over two decades. However, quality of diet also improved. 
Food access is directly associated with purchasing potential of the people, a person don't have access to the food even though it is available in the market. Thus insufficient livelihood opportunities in rural areas are responsible for household nutrition insecurity [8]. It refers to the adequate resources to required appropriate foods for nutritious diet by individuals and households [13,14]. It is entails on the elements such as affordability, allocation and preferences [9]. There are two sorts of food access such as direct access refers as household produced food by utilizations of human and non-human resources and while economic access refers as household purchased food that produced at somewhere else. Household assets may include their income, access to, use of and/or ownership of land, livestock, labor and the products of labor inheritance, gifts and transfers can determine to the access of food [10]. According to FAO food access is based on two pillars such as economic and physical access. Economic access is reflected by food prices, disposable income, provision and access to social support while physical access is based on quality of infrastructure (roads, ports, railways, communications and storage facilities) and other installations that facilitates the markets. Poverty rate reduction has been reflected to improvement in food access. Poverty rates fell from $47 \%$ to $24 \%$ in 2008 , Whereas undernourishment rates declined $24 \%$ to $15 \%$ in developing countries since 1990 to 2010 [15].

Food utilization refers to the metabolizaton of food by human body [16]. It is suggested that food security cannot be achieved without utilization of food. However, availability and access of food not ensure to alleviate food insecurity. Perhaps, it has been investigated that household do not utilize food due to inadequate nutrition education and food preparation, bad habits, eating disorder and intestinal parasites [9]. Food utilization is associated with elements such as nutritional value, social value and food safety. Hence nutritional values of the individuals and household have been decided food choice. Food utilization has been influenced by the preparation, processing, and cooking of food [10].

Food stability refers to the consistent supply of food at national, household and individual level which is directly affected by the agriculture sector performance. In developing countries a quite small proportion of consumer would be able to store food for whole year. It requires proper management of domestic production, rational use of buffer stock, trade and food market integration [17]. It is the ability of individuals or household to obtain food over a period of time. This type of food insecurity can be in the shape of transitory (food unavailable in certain time period, seasonal (based on regular pattern on growing seasons in food production, and chronic (persistent lack of adequate food. Consequently, chronic and transitory food insecurity closely related with each other and resultantly in the reoccurrence of transitory food security can make people more vulnerable to chronic food insecurity [10].

\section{Material and Methods}

In this research secondary data has been used. We have taken major food crops like wheat, rice and sugarcane. The data has been collected about their area of cultivation, crops productivity per annum, and yield of crops. The objective of this data is to check the growth and improvement in the cultivation area, crops productivity and yield during the specific period of time. The data of this study about major food crops have taken from year 1997 to 2013. Particularly the source of this data is Economic survey of Pakistan and Pakistan bureau of statistics. This secondary data is designed to evaluate the growth and development of major food crops in the context of three variables of area, production and yield. For this purpose SPSS-16 has been used to examine the required results. Furthermore, in current study different latest reports such as Global Hunger Index 2013, Global Food Security Index 2013, Internal Displacement Monitoring Center (IDMC) report about North West internally displaced persons (IDPs) of Pakistan -2013 and United States Department of Agriculture (USDA) data has been used to explore the state of food security at different level around the world especially in Pakistan.

\subsection{State of Global Food Supply \& Demand}

\section{Results and Discussion}

Agriculture and forestry sector has been account for $2 \%$ of the total world energy used and the total $38.5 \%$ land area has dedicated to agriculture [15]. Food production comes from 1.5 billion ha globally of cultivated land which represent $12 \%$ of the total land area [18]. According to the Food and Agriculture Organization (FAO), World agricultural production growth has been expected to fall by $1.5 \%$ per year to 2013 and then a more reduction by $0.9 \%$ to 2050 in comparison with $2.3 \%$ growth per year since 1961, although cropland has been reduced by $13 \%$ and pasture by $4 \%$ [53]. Substantially, agricultural growth has been declined in 2009 relative to the growth of 2000. This deceleration in growth has been affect world food security [14]. It is suggested that future food supply will be managed as prudent management of agricultural resources, investment in effective technologies along with efficient reforms in policies and institution to accomplish substantial increase in food production [ 19]. Hence food demand measures would be implausible to be a pathway, as food traditions and human diets which might be extremely difficult to influence [20,21], as income grows [22]. It is found that global demand of agricultural crops has been increasing and this trend may continue to do so, despite 
that global population also increase by a 2.3 billion person and anticipated greater per capita income through this midcentury [12]. However, land cleaning and intensive use of existing croplands may contribute to increased crop production needed to accomplish such global demand but environmental impacts and tradeoffs of these alternative paths of agricultural expansion are ambiguous [23].

It has been divided the top 100 large nations into seven economic groups ranging from A-G, group A highest to group $\mathrm{G}$ lowest national average per capita real (inflation adjusted) gross domestic product (GDP) that comprised $91 \%$ of the 2006 global population. The objective is to determine long term global trends and better control of economic differences among nations. It is investigated that global demand for crop calories and crop protein would increase by $100 \% \pm 11 \%$ and $110 \% \pm 7 \%$ (mean \pm SE) since 2005 to 2050 [24].

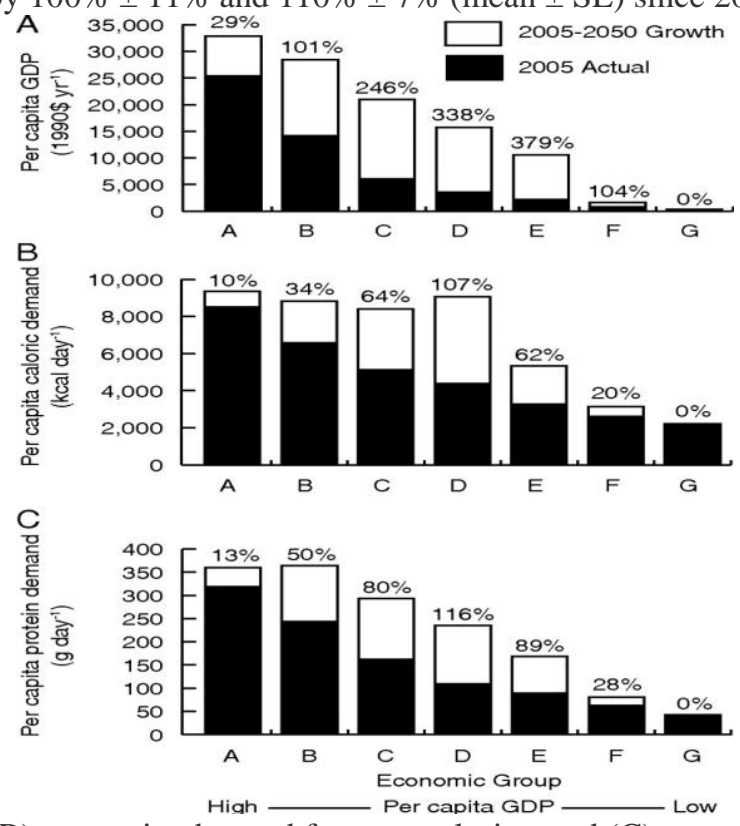

Fig.1. (A) Per capita GDP, (B) per capita demand for crop calories, and (C) per capita demand for crop protein in 2005 (black) and mean projected 2050 increases (white represent increases above bars) [24].

It is reported that major cereals yields as linear growth and projected a $79 \%$ increase in demand for all foods in 2050 over 2000 levels, besides that an increase in supply of 57\% (71\% for cereals). Thus, rapid change will result in a $44 \%$ increase in prices in real terms over 2000 levels. Consequently it is concluded that global farm output will need to almost double in the first half of this century in order to maintain such historic trends in real prices for food [26]. In fact population growth rate is decreasing. Population is expected to exceed 6.9 billion and it has been increasing at $1.15 \%$ in 2010 . While it is projected to be 9.15 billion by 2050 and growing at rate of $0.35 \%$ per annum. As projected linear increase in yields will continue persistent till 2050. Perhaps projected population growth rate is lower than the rate of cereal yields. However, due to the increase in people income their dietary preferences will be changed from cereals to meat consumption which leads to decline in conversion efficiency. Therefore, increased demand for cereals as feed grains, than demand of grains will ultimately increase at a greater rate as compared to the population [27]. Rosegrant et al. (2009) suggested that industrial countries might consume $150 \mathrm{Kg}$ capita/maize per year for ethanol production by 2020 that is similar to the rate of cereals food consumption in developing countries [25]. World annual percentage increase in yield and population is stated in (Table 1).

Table 1. Annual Percentage Increase in Population \& Yield

\begin{tabular}{|l|l|l|l|}
\hline Year & $\mathbf{2 0 1 0}$ & $\mathbf{2 0 3 0}$ & $\mathbf{2 0 5 0}$ \\
\hline$\%$ annual increase in Yield & 1.24 & 0.99 & 0.80 \\
\hline$\%$ annual increase in Population & 1.15 & 0.67 & 0.35 \\
\hline
\end{tabular}

Source: Edmeades, G. et al. (2010)

\subsection{Drivers Impacting on Food Supply and Consumption Patterns}

Water is an important for crops production. There is about $40 \%$ of world population live such geographic regions that directly compete for shared trans- boundary water resources [28]. A water shortage has been reflected in the per capita decline in irrigation water use for food production worldwide during the past 20 years. Perhaps water resources are critical for irrigation which has under stress as rapid growth in populous 
cities, states, regions and countries [29]. In china more than 300 cities are facing intensifying shortage of water [30]. Climatic change will have strong impact on crop productivity which has implications for food security [31]. It is found that a $50 \%$ decline in South Asian wheat production by 2050 which is equal to about $7 \%$ of the global crop production [32]. It is stated that agricultural production might fell $10 \%$ to $25 \%$ in developing countries in the case of unabated global warming, while india's agricultural capacity could fall much about $40 \%$ [33]. In the last decade high energy prices have been driving up the cost of farming through higher prices of fuel and fertilizer [34], resulting high energy prices also raise food prices by increased cost of transporting and shipping. Similarly, high energy prices also influential on the demand side [35]. The credit crises have become the cause of additional stagflation i.e high prices and low growth along with stagflation owed to the energy crises [36]. Credit crisis had a significant source of capital contraction effect in the globalized economy. Similarly less capital lead to the less investment which will ultimately produce the lower agricultural production. In this regard, high cost of credit means definitely higher cost of food production in smallholder systems resulting as few save and borrow many [37]. Despite these there are enormous factors might effect on the supply side of food such as a reduction in per capita arable land, faster decline in soil fertility [38], decline in investments in the field of agricultural research [39,40]. Mainly in Asia, most fertile lands are being exploited, thus increase in food production may be accomplished by enhancing crops yields. Crops yields is stagnating, technology and productivity fatigue are the obstacles in improving crops yields [14].

During last few decades, it is projected to rise in per capita income at a rate of $2 \%$ annually, it is starting from low base to rise at even higher level rate in developing countries [41] and household avail high fat foods as their income increased [42]. Particularly increased in income have been considered as good to acquired better quality diets, lower morbidity, better health care and mortality from various diseases and lower risk of obesity. This phenomenon has been noticed in most industrial countries such as USA and UK [43]. In fact in the coming decade's population growth will be based on urban areas. Today more than 50\% population has been inhabited in cities while this figure was $10 \%$ in 1990. Consequently, urbanizations have been growing fast in those countries that has vast majority of rural population. However in industrial countries urbanization grow quite slow because those countries are already dominated along with urban population. Subsequently urbanization has some numerous consequences which leads to access of good distribution infrastructure, improved marketing, and supermarkets as dominated by multinationals, better transportation and improving access to foreign suppliers and acknowledge the importance of imports in the overall food supply [44]. In fact rapid urbanization has been sustained reflective effect on food consumption [45]. It is found that trade liberalization has been ensured greater availability and affordability highly processed food, nutrient-poor foods, animal products and calorie rich in developing countries [46]. It facilitates the removal of foreign investment barriers in food distribution to making availability of certain foods items in specific country. Similarly it encouraged the types of food retails such as multinational fast food outlets have been made investment developing countries [47]. Franchises and manufacturers (KFCs, McDonalds, Nestle, and Kraft) are drivers of the fast food markets, western life style that have been becoming recognized and widespread in developing countries. These types of organizations are called transnational food corporations (TFCs) [48]. It has been increased the consumption patterns of modern processed food from developed countries. Thus developing countries have been availing rich calorie food as being modern processed food and such type of food is cheap through utilization of modern technology and numerous advances in food processing capacities [49]. Recently supermarkets are major players of agri food economy in Latin America. Approximately, Supermarket had share of $60 \%$ of the national retail sector of South America and Mexico [50]. Perhaps super markets offer attractiveness of convenience along with more features to urban consumers. It also increased the availability of less healthy, cheaper, higher fat and salt laden foods in developing countries [51]. Although it is found that health awareness continues to spread extensive health information going hand in hand with the ageing of populations and instantly increased risk for lifestyle diseases. However, consumer involvement about sustainability has been increased radically and it is found that certainty and perceived consumer effectiveness was found to be directly associated with significant positive attitude and intentions to buy sustainable food products [52].

\subsection{Pakistan State of Food Insecurity}

Pakistan is an agricultural economy, thus agriculture sector plays a key role in the development of the country and being a dominant sector it contributes $21.4 \%$ in the GDP and employed $45 \%$ of the population. There are two crop seasons namely "Kharif is the first season which is started to sowing April-June and harvested in October and December, While Rabi that begins sowing in October -December and harvesting initiated in April-May. There are major corps (wheat, cotton, sugarcan, maize,rice) that contribute $25.2 \%$ and $5.4 \%$ to overall agriculture value added and GDP respectively. While minor crops (sunflower, masoor,bajra, jawar, gram, barley,tobbaco etc) that account for $12.3 \%$ of the overall value added to agriculture. Wheat is the main dietary staple food for one of the largest population of the Pakistan. Although per capita wheat consumption rate is very high $124 \mathrm{~kg} / \mathrm{year}$ across the worldwide for the population of 180 million and 
population is growing rapidly at the rate of $2.03 \%$ per annum. In Pakistan wheat flour is called "atta" which is a staple that provides around $72 \%$ calorific energy in the average diet. Pakistan is the 6th largest country in the world to producing wheat. Traditionally, rice local consumption is about $45 \%$ of total production in Pakistan and rest has been exported. Specifically, Pakistan has been producing more than enough food for selfconsumption even though wheat and rice exported to different countries.

Pakistan is facing food insecurity in all the country that is reflected in the $61 \%$ districts ( 80 out of 113 ). However, this is the sharp increase in the state of food insecurity particularly half of the population (48.6\%) does not have access to sufficient and healthy food at all times. There are substantial evidences that show facts of food insecure population existed in different areas such as FATA (67.7\%), Baluchistan (61.2\%), KPK (56.2\%), Sindh (44.3\%), Punjab (38.5\%) and Islamabad (23.6\%). In this way 20 districts of Pakistan has been indulge in worst condition of food insecurity. Particularly, population has been facing food insecurity due to access and affordability. Consequently, Pakistan global hunger index score is 19.3 in 2013 that shows the serious level of hunger in the country, but this GHI score is little better relative to 1990 score figure which was 25.9 point. [54]. In Contrast Pakistan's improvement has been as quite little it is just 6.6 points due to the poor effort during the past two decades. India and Bangladesh have been jumped 32.6 to 21.3 and 36.7 to 19.4 points in GHI respectively during the same period 1990-2013. Similarly, according to global food security index Pakistan secure 39.7 points out of 100 that score is lower than India (44.4) and more than Bangladesh (35.3) [55]. During last 16 years period since 1997-98 to 2012-13 major foods crops production is not satisfactory in respect of production and yield along with there is not significant improvement in the area cultivation. Therefore, maximum production of wheat (25214000 tonnes 2010-11), Rice (6952000 tonnes 2008-09) and sugarcane (63920000 tonnes 2007-08) and current state (2012-13) of such crops is lower as compared to stated values. Perhaps, food crops production, yield and cultivation area status is stagnant. This scenario might be harmful to accommodate the future demands for the large population. Furthermore, statistics of three variables are stated (Table 2).

Table 2. Statistics of Area, Production and Yield

\begin{tabular}{|c|c|c|c|}
\hline Wheat & Area Hectares $(000)$ & Production (Tonnes 000) & Yield (Kg/Hec.) \\
\hline Mean & 8493.31 & 21310.56 & 2504.06 \\
\hline Std. Deviation & 330.561 & 2385.745 & 202.670 \\
\hline Minimum & (2002-2003) 8034 & (1998-99) 17858 & $(1998-99) 2170$ \\
\hline Maximum & $(2009-2010) 9132$ & $(2010-11) 25214$ & $(2010-11) 2833$ \\
\hline Current State (2012-13) *P & 8693 & 24231 & 2787 \\
\hline \multicolumn{4}{|l|}{ Rice } \\
\hline Mean & 2485.12 & 5256.62 & 2105.25 \\
\hline Std. Deviation & 218.945 & 854.025 & 188.299 \\
\hline Minimum & $(2001-2002) 2114$ & $(2001-2002) 3882$ & $(2001-2002) 1836$ \\
\hline Maximum & (2008-2009) 2963 & (2008-2009) 6952 & $(2011-2012) 2398$ \\
\hline Current State $(2012-13) * \mathrm{P}$ & 2311 & 5541 & 2398 \\
\hline \multicolumn{4}{|l|}{ Sugarcane } \\
\hline Mean & 1040.06 & 52372.44 & $5.03 \mathrm{E} 4$ \\
\hline Std. Deviation & 85.743 & 5929.545 & $3.349 \mathrm{E} 3$ \\
\hline Minimum & $(2005-06) 907$ & $(2000-01) 43606$ & $(2000-01) 45376$ \\
\hline Maximum & $(2007-08 \quad 1241$ & $(2007-08) 63920$ & $(2010-11) 55981$ \\
\hline Current State (2012-13) *P & 1124 & 62472 & 55580 \\
\hline
\end{tabular}

\section{*P: Provisional}

Pakistan is sixth largest country of the world and $2^{\text {nd }}$ largest in the South Aisa. it has population of 184.35 million as on July $1^{\text {st }} 2012-13$ and growth rate is $2.03 \%$ whereas Asia growth rate is $0.9 \%$ in year $2012[1]$.

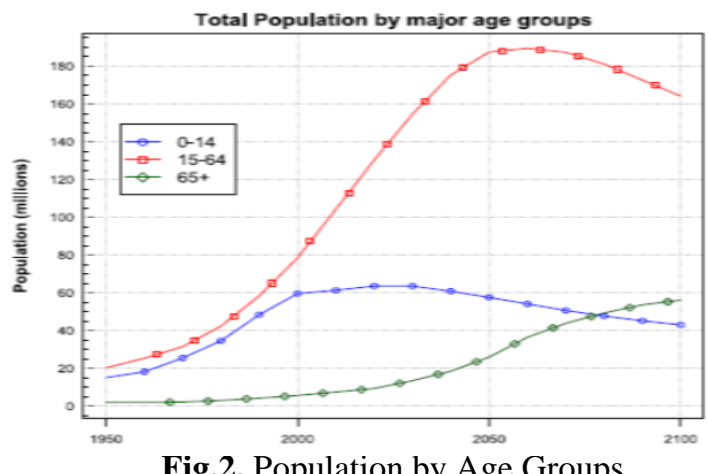

Fig.2. Population by Age Groups

Besides population growth and another challenge is urbanization which is critical for country especially in respect of food consumption and along with food availability in markets. No doubt population growth and urbanization move together, thus economic development is correlated with urbanization. This increase the 
individual income level, substantially urbanization growing very fast in Pakistan in this manner population in urban areas increased from 58.74 million in 2008 to 69.87 million in 2013. Similarly urbanization growth rate and population is presented (Table 3).

Table 3. Population and Urban Growth Rate

\begin{tabular}{|l|l|l|l|}
\hline Indicators & $\mathbf{1 9 9 5}$ & $\mathbf{2 0 1 0}$ & $\mathbf{2 0 2 5}$ \\
\hline Rural population (000) & 86804 & 111304 & 128341 \\
\hline Urban population (000) & 40542 & 62290 & 92268 \\
\hline Percentage urban (\%) & 31.8 & 35.9 & 41.8 \\
\hline
\end{tabular}

\section{Source: UN, Department of Economic and Social Affairs}

Average inflation rate in Pakistan is 8.03\% since 1957 until 2014, during this period 37.81\% recorded high and $-10.32 \%$ in December 1973 and February 1959 respectively. Similarly last month January 2014 it was recorded $7.90 \%$, hence in consumer price index food items have $35 \%$ total weight which is the largest in comparison of other items. This high rate of inflation creates issue of food insecurity in term of affordability in Pakistan. Federally Administered Tribal Areas (FATA), Blochistan and KPK have been found to be respectively extremely insecure food and food insecure. The reason of this food insecurity is the level of destruction in (FATA) caused by instability of peace and also the number of persons forced to flee their homes in relation to the conflict with Taliban. There are 1.1 million IDPs have registered due the conflict in the north west where as many more are unregistered in the region or somewhere else. Specifically, as a whole 5 million people have been displaced by conflict since 2004 and 15 million people had displaced across the country during flooding 2010-2012 [56]. A large numbers of fatalities about 16578 including (civilians 2225, security forces 1151, and militants 13202) have been occurred due to conflict in North West area of Pakistan [57]. Particularly instability of peace is the great challenge for Pakistan in the area of FATA to ensuring food security. Despite that Pakistan has been facing the problem of water scarcity, food production, processing and packaging, distribution related issues which leads to food insecurity.

\section{Conclusion}

The comprehensive picture of reviews theme contributes to describe the various challenging facing humanity in maintaining per capita food production. Particularly, World has been concentrating on reducing number of people who suffer hunger and malnutrition. They provide a number of mechanisms for optimism in order to tackles rapid growth of population, diversifying food demand and consumption patterns. The urgent actions has required for yield growth opportunities through the application of traditional and novel science. Perhaps, it is realized that significant yield gain that could be obtained by working closely with farmers to deploy existing resources and knowledge through education and more social and economic equality. More importantly, it is advised to taking a "competing risks" approach to regulation in food system at national and global level. Millennium Development Goals has enforced to nations to take initiatives in order to reducing poverty, hunger and food insecurity. Specifically, Pakistani farmers have been facing a lot of problems in respect of high energy, water scarcity other input prices and supply chain critical issues to input acquisitions and output distribution in wide spread areas. Mainly traders have more power and control on the prices of inputs and outputs in all over the country which makes farmers much more disappointed from this profession. Thus, Pakistan requires a deep understanding about how agricultural policies affect food supply, demand and incomes for effective management of food security. Consequently, Pakistan food security and sovereignty need to increase in those areas where hungry live and take some effective measures to ensure stability of peace and development of infrastructure in the affected areas (i.e. FATA). Furthermore, there are greater opportunities of agricultural intensification and extensification that could be capitalized by developing agri-friendly policies at national level. This study highlighted comprehensive picture of various problems that World has been observed in the context of food demand and supply. Future research might be conducted in respect of overall critical evaluations and analysis of food supply chain for assurance of food security.

\section{References}

[1] Shaw, D. J., \& Clay, E. J. (1998). Global hunger and food security after the World Food Summit. Canadian Journal of Development Studies/Revue canadienne d'études du développement, 19(4), 55-76.

[2] FAO (2009) Declaration of the World Food Summit on Food Security. Rome: Food and Agriculture Organization of the United Nations.

[3] Bickel, G., Nord, M., Price, C., Hamilton, W., \& Cook, J. (2000). Guide to measuring household food security. Alexandria. Department of Agriculture Food and Nutrition Service.

[4] Smith, M., Pointing, J., \& Maxwell, S. (1993). Household food security: concepts and definitions: an annotated bibliography (Vol. 8). Institute of Development Studies.

[5] Timmer, C. P. (2005). Food security and economic growth: an Asian perspective. Asian-Pacific Economic Literature, $19(1), 1-17$.

[6] Pinstrup-Andersen, P. (2009). Food security: definition and measurement. Food Security, 1(1), 5-7.

[7] Fullbrook, D. (2010). Food as security. Food Security, 2(1), 5-20. 
[8] Swaminathan, M. S. (2006). Science and shaping our agricultural future (pp. 155-183). The Australian National University Press, Canberra.

[9] Gregory, P. J., Ingram, J. S., \& Brklacich, M. (2005). Climate change and food security. Philosophical Transactions of the Royal Society B: Biological Sciences, 360(1463), 2139-2148.

[10] FAO (1997). The food system and factors affecting household food security and nutrition" Agriculture, food and nutrition for Africa: A resource book for teachers of agriculture

[11] Ecker, O., \& Breisinger, C. (2012). The food security system: A new conceptual framework (No. 1166). International Food Policy Research Institute (IFPRI).

[12] Godfray, H. C. J., Beddington, J. R., Crute, I. R., Haddad, L., Lawrence, D., Muir, J. F., ... \& Toulmin, C. (2010). Food security: the challenge of feeding 9 billion people. science, 327(5967), 812-818.

[13] Sen, A. (1982). Poverty and famines: an essay on entitlement and deprivation. Oxford University Press.

[14] Timmer, C. P. (2000). The macro dimensions of food security: economic growth, equitable distribution, and food price stability. Food Policy, 25(3), 283-295.

[15] FAO, IFAD and WFP. 2013. The State of Food Insecurity in the World 2013. The multiple dimensions of food security. Rome,

[16] Tweeten, L. (1999). The economics of global food security. Review of Agricultural Economics, 21(2), 473-488.

[17] FAO (Food and Agriculture Organisation) (2002) The Sate of Food Insecurity in the World 2001. Rome: Food and Agriculture Organisation of the United Nations.

[18] FAO, 2003. World Agriculture: Towards 2015/2030. An FAO Perspective. Food and Agriculture Organization of the United Nations/Earthscan, Rome, Italy/USA.

[19] Herrero, M., Thornton, P. K., Notenbaert, A. M., Wood, S., Msangi, S., Freeman, H. A., ... \& Rosegrant, M. (2010). Smart investments in sustainable food production: revisiting mixed crop-livestock systems.

[20] Alexandratos, N. (2008). Food price surges: possible causes, past experience, and longer term relevance. Population and Development Review, 34(4), 663-697.

[21] Stokstad, E. (2010). Could less meat mean more food?. Science, 327(5967), 810-811.

[22] Mancino, L., Kuchler, F., \& Leibtag, E. (2008). Getting consumers to eat more whole-grains: the role of policy, information, and food manufacturers. Food Policy, 33(6), 489-496.

[23] The Government Office for Science (2011) Foresight. The Future of Food and Farming. Final Project Report (The Government Office for Science, London).

[24] Tilman, D., Balzer, C., Hill, J., \& Befort, B. L. (2011). Global food demand and the sustainable intensification of agriculture. Proceedings of the National Academy of Sciences, 108(50), 20260-20264.

[25] Rosegrant, M. W., Ringler, C., Sinha, A., Huang, J., Ahammad, H., Zhu, T., ... \& Batka, M. (2009). Exploring Alternative Futures for Agricultural Knowledge, Science and Technology (AKST). Australian Centre for International Agricultural Research (ACIAR).

[26] Tweeten, L., \& Thompson, S. R. (2009). Long-term global agricultural output supply-demand balance and real farm and food prices. Farm Policy Journal,6(1), 1-16.

[27] Edmeades, G. O., Fischer, R. A., \& Byerlee, D. (2010, November). Can we feed the world in 2050. In Proceedings of the New Zealand Grassland Association(Vol. 72).

[28] Yoffe, S., Fiske, G., Giordano, M., Giordano, M., Larson, K., Stahl, K., \& Wolf, A. T. (2004). Geography of international water conflict and cooperation: Data sets and applications. Water Resources Research, 40(5).

[29] Gleick, P. H. (2003). Water use. Annual review of environment and resources,28(1), 275-314.

[30] Khan, S., Hanjra, M. A., \& Mu, J. (2009). Water management and crop production for food security in China: a review. Agricultural water management,96(3), 349-360.

[31] Spash, C. L. (2007). The economics of climate change impacts à la Stern: Novel and nuanced or rhetorically restricted?. Ecological Economics, 63(4), 706-713.

[32] De Fraiture, C., \& Wichelns, D. (2010). Satisfying future water demands for agriculture. Agricultural Water Management, 97(4), 502-511.

[33] Cline, W. R. (2007). World Agriculture Faces Serious Decline from Global Warming. Centre for Global Development, Washington, DC.

[34] World Bank, 2008. World Development Report 2008: Agriculture for Development. The World Bank, Washington, DC.

[35] Pimentel, D., 2007. Biofuels: energy and environmental issues. Farm Policy Journal 4 (2), 61-67.

[36] Graafland, G.B., 2008. Global Future Analysis. Planck Foundation, The Netherlands.

[37] Zeller, M., \& Sharma, M. (2000). Many borrow, more save, and all insure: implications for food and micro-finance policy. Food policy, 25(2), 143-167.

[38] Lal, R. (2004). Soil carbon sequestration impacts on global climate change and food security. science, 304(5677), 1623-1627.

[39] Hanjra, M. A., \& Gichuki, F. (2008, August). Investments in agricultural water management for poverty reduction in Africa: case studies of Limpopo, Nile, and Volta river basins. In Natural Resources Forum (Vol. 32, No. 3, pp. 185-202). Blackwell Publishing Ltd.

[40] Pingali, P. (2007). Westernization of Asian diets and the transformation of food systems: implications for research and policy. Food Policy, 32(3), 281-298.

[41] Du, S., Mroz, T. A., Zhai, F., \& Popkin, B. M. (2004). Rapid income growth adversely affects diet quality in China-particularly for the poor!. Social science \& medicine, 59(7), 1505-1515.

[42] Kearney, J. (2010). Food consumption trends and drivers. Philosophical transactions of the royal society B: biological sciences, 365(1554), 2793-2807.

[43] Marmot, M. (2001). Income inequality, social environment, and inequalities in health. Journal of policy Analysis and Management, 20(1), 156-159.

[44] Hawkes, C. 2006 Uneven dietary development: linking the policies and processes of globalization with the nutrition transition, obesity and diet-related chronic diseases. Global Health $2,1$.

[45] Popkin, B. M. 1999 Urbanization, lifestyle changes and the nutrition transition. World Dev. 27, 1905-1916. (doi:10. 1016/S0305750X(99)00094-7)

[46] Thow, A. M. 2009 Trade liberalisation and the nutrition transition: mapping the pathways for public health nutritionists. Public Health Nutr. 12, 2150. (doi:10.1017/S1368980009005680).

[47] Thow, A. M. \& Hawkes, C. 2009 The implications of trade liberalization for diet and health: a case study from Central America. Global Health 28, 5. (doi:10.1186/1744-860

[48] Hawkes, C. 2005 The role of foreign direct investment in the nutrition transition. Public Health Nutr. 8, 357-365. (doi:10.1079/PHN2004706) 
[49] ] Popkin, B. M. 2006 Technology, transport, globalization and the nutrition transition food policy. Food Policy 31, 554- 569. (doi:10.1016/j.foodpol.2006.02.008)

[50] Reardon, T., Timmer, C. P., Barrett, C. B. \& Berdegue', J. 2003 The rise of supermarkets in Africa, Asia, and Latin America. Am. J. Agric. Econ. 85, 1140-1146. (doi:10.1111/j.0092-5853.2003.00520.x)

[51] Kearney, J. (2010). Food consumption trends and drivers. Philosophical transactions of the royal society B: biological sciences, 365(1554), 2793-2807.

[52] Vermeir, I. \& Verbeke, W. 2006 Sustainable food consumption: exploring the consumer 'attitude-behavioral intention' gap. J. Agric. Environ. Ethics 19, 169-194. (doi:10.1007/s10806-005-5485-3)

[53] FAO. 2003. The State of Food Insecurity in the World 2013. Monitoring progress towards the World Food Summit and Millennium Development Goals

[54] von Grebmer, K., D. Headey, C. Béné, L. Haddad, T. Olofi nbiyi, D. Wiesmann, H. Fritschel, S. Yin, Y. Yohannes, C. Foley, C. von Oppeln, and B. Iseli. 2013. 2013 Glo- bal Hunger Index: The Challenge of Hunger: Building Resilience to Achieve Food and Nutrition Security. Bonn, Washington, DC, and Dublin: Welthungerhilfe, International Food Policy Research Institute, and Concern Worldwide.

[55] Global food security index 2013 An annual measure of the state of global food security, The Economist, Intelligence Unit

[56] IDMC, 2013. North-West Pakistan,. Massive new displacement and falling returns require rights-based response

[57] South Asian Terrorism Portal-profiles", satp.org, database retrieved on 01-15-2014 